\title{
Strategi Pembelajaran Sejarah Kebudayaan Islam Melalui Pendekatan Saintifik dii MIN 4 Muaro Jambi
}

\author{
Dr. Nurhuda, S.Pd., M.Pd \\ Institut Agama Islam Tebo Jambi, Indonesia \\ nurhuda.tebo@yahoo.com
}

\begin{tabular}{l}
\hline open \\
access \\
*Penulis Korespondensi \\
\hline Histori Artikel: \\
Submit: 2022-02-07 \\
Diterima: 2022-02-07 \\
Dipublikasikan: 2022-02-07 \\
\hline Kata Kunci: \\
Strategi Pembelajaran, Sejarah \\
Kebudayaan Islam, Pendekatan \\
Saintifik \\
\hline
\end{tabular}

\begin{abstract}
ABSTRAK
Permasalahan yang ditemukan oleh penulis di Madrasah Ibtidaiyah Negeri 4 Muaro Jambi adalah: pertama, ketika terjadi pembelajaran Sejarah Kebudayaan Islam ternyata guru mata pelajaran tersebut mendapat kesulitan dalam tahapan mengamati, dimana guru mata pelajaran SKI belum mampu membuat siswa fokus pada gambar atau teks karena siswa malah asyik bercanda dengan teman sebangku. Kedua, dalam tahapan menanya, penulis menemukan bahwa guru mata pelajaran SKI lebih aktif bertanya dibandingkan siswanya. Penelitian ini dilakukan dengan tujuan untuk mengetahui bagaimana strategi pembelajaran pembelajaran Sejarah Kebudayaan Islam melalui pendekatan saintifik di MIN 4 Muaro Jambi. Metode yang digunakan dalam penelitian ini adalah kualitatif deskriptif dengan pendekatan studi penelitian. Hasil penelitian ini menyimpulkan bahwa strategi pembelajaran dengan pendekatan saintifik pada mata pelajaran Sejarah Kebudayaan Islam di MIN 4 Muaro Jambi guru sudah menjabarkan kurikulum untuk menggunakan pendekatannya ini. Pada pelaksanaanya pendekatan ini tidak sepenuh sesuai perencanaan karena banyak aspek yang menjadi permasalahan seperti siswa bertanya yang sedikit, kemampuan bernalar yang rendah, kemampuan mengasosiasi yang keterbatasan media dan waktu.
\end{abstract}

\begin{abstract}
Jurnal Pendidikan Sains dan
Komputer is licensed under a Creative Commons AttributionNonCommercial 4.0 International (CC BY-NC 4.0).
\end{abstract}

\section{LATAR BELAKANG}

Pembelajaran merupakan suatu sistem, karenanya setiap aktivitas mengajarkan harus didesain terlebih dahulu alternatif pilihan dalam menentukan strategi pembelajaran yang tepat. Hal ini berarti bahwa guru benar-benar memperhatikan serta dapat menggunakan strategi pembelajaran yang sesuai dan tepat dengan materi pelajaran yang akan disampaikan kepada siswa, sehingga hasil belajar siswa dapat dicapai sesuai dengan tujuan pembelajaran yang ditetapkan.

Dalam proses pembelajaran, anak kurang didorong untuk mengembangkan kemampuan berfikir. Proses pembelajaran di dalam kelas diarahkan kepada kemampuan anak untuk menghafal informasi, otak anak dipaksa untuk mengingat dan menimbun berbagai informasi tanpa dituntut untuk memahami informasi yang diingat itu untuk menghubungkannya dengan kehidupan sehari-hari. Akibatnya, ketika anak didik kita dari sekolah mereka pintar secara teoritis, tetapi mereka miskin aplikasi. Maka dengan strategi pembelaran yang tepat seperti penggunaan pembelajaran saintifik dimaksudkan bisa memberikan perbaikan bagi hasil belajar siswa.

Dalam buku Strategi Belajar dan Pembelajaran: Implementasi Kurikulum 2013 karangan E. Kosasih yang diterbitkan Yrama Widia Bandung Tahun 2014 halaman 72-73 dikatakan bahwa langkah-langkah pembelajaran saintifik terdiri atas lima pengalaman belajar pokok yaitu: mengamati, menanya, menalar, mengasosiasi dan mengkomunikasikan (mengkreasikan). Kelima tahapan ini merupakan proses yang berkesinambungan yang diharapkan pula selalu bersinggungan dengan ranah sikap, pengetahuan dan 


\section{Jurnal Pendidikan Sains dan Komputer}

keterampilan. Selama proses pembelajaran berlangsung, ketiga ranah itu dapat berkembang pula dengan baik. Para siswa tidak sekedar tahu (apa), tetapi juga bisa (bagaimana) dan memperoleh perubahan sikap (mengapa) atas proses pembelajaran yang dilakoninya. ${ }^{1}$

Permasalahan yang ditemukan oleh penulis di Madrasah Ibtidaiyah Negeri 4 Muaro Jambi, adalah: pertama, ketika terjadi pembelajaran Sejarah Kebudayaan Islam (SKI) ternyata guru mata pelajaran tersebut mendapat kesulitan dalam tahapan mengamati, dimana guru mata pelajaran SKI belum mampu membuat siswa fokus pada gambar atau teks karena siswa malah asik bercanda dengan teman sebangku. Kedua, dalam tahapan menanya, penulis menemukan bahwa guru mata pelajaran SKI lebih aktif bertanya dibandingkan siswanya.

\section{Strategi Pembelajaran}

\section{STUDI LITERATUR}

Strategi adalah perencanaan untuk mencapai sesuatu. ${ }^{2}$ Strategi adalah suatu garis-garis besar haluan untuk bertindak dalam usaha mencapai sasaran yang telah ditentukan. ${ }^{3}$ Dengan demikian, strategi adalah cara yang teratur dalam melakukan kegiatan secara berurutan atau sistematis dan kalimat terpikir baik-baik dimaksudkan dengan langkah yang terencana atau terprogram.

Strategi pembelajaran mempunyai pengertian suatu garis-garis besar haluan untuk bertindak dalam usaha mencapai sasaran yang telah ditentukan, dihubungkan dengan belajar mengajar. Strategi bisa diartikan sebagai pola-pola umum kegiatan guru dan anak didik dalam menifestasi aktivitas pengajaran. ${ }^{4}$ Strategi pembelajaran diartikan sebagai: Perencanaan yang berisi tentang rangkaian kegiatan yang didesain untuk mencapai tujuan pendidikan tertentu. Strategi pembelajaran merupakan rencana tindakan (rangkaian kegiatan) termasuk penggunaan metode dan pemanfaatan berbagai sumber daya atau kekuatan dalam pembelajaran yang disusun untuk mencapai tujuan tertenu. Dalam hal ini adalah tujuan pembelajaran. ${ }^{5}$

Strategi pembelajaran di dalam kelas (sekolah) sangat menuntut adanya aktivitas belajar siswa yang tinggi, karena tinggi rendahnya aktivitas belajar akan sangat menentukan prestasi belajar yang akan dicapai siswa. Oleh sebab itu perangsangan aktivitas belajar siswa harus dilaksanakan sejak dini, yakni melalui pendidikan sekolah, keluarga, dan lingkungan masyarakat. Bagi siswa yang baik tentunya akan selalu menyadari akan adanya tuntutan yang akan datang dari dunia pendidikan dengan meningkatkan aktivitas di dalam belajarnya dengan cara mempelajari setiap mata pelajaran yang telah diprogramkan pada umumnya.

\section{Pendekatan Pembelajaran Saintifik}

Pendekatan pembelajaran dapat diartikan kumpulan metode dan cara yang digunakan oleh tenaga pendidik dalam melakukan pembelajaran. Dalam strategi terdapat sejumlah pendekatan, dalam pendekatan

${ }^{1}$ E. Kosasih, Strategi Belajar dan Pembelajaran: Implementasi Kurikulum 2013 (Bandung: Yrama Widia, 2014), hlm. 72-73.

${ }^{2}$ Wina Sanjaya, Strategi Pembelaran Berorientasi Standar Proses Pendidikan (Jakarta: Kencana, 2011), hlm. 127.

${ }^{3}$ Syaiful Bahri Djamarah dan Aswan Zain, Strategi Belajar Mengajar, Jakarta: Rinek Cipta, 2002, hlm. 5.

${ }^{4}$ Ahmad Rohani, Pengelolaan Pengajaran (Jakarta: Rineka Cipta, 2004), hlm. 31.

${ }^{5}$ Departemen Pendidikan Nasional, Strategi Pembelajaran dan Pemilihannya, (Jakarta: Direktorat Tenaga Kependidikan, 2008), hlm. 3. 


\section{Jurnal Pendidikan Sains dan Komputer}

terdapat sejumlah metode, dalam metode terdapat sejumlah teknik, dalam teknik terdapat sejumlah taktik pembelajaran. Dari penerapan semua kegiatan pembelajaran akan memunculkan model pembelajaran. ${ }^{6}$

Salah satu pendekatan yang dapat digunakan dalam pembelajaran adalah pendekatan saintifik, yaitu pendekatan yang menggunakan langkah-langkan serta kaidah ilmiah dalam proses pembelajaran. Langkah ilmiah yang diterapkan meliputi menemukan masalah, merumuskan masalah, mengajukan hipotesis, mengumpulkan data, menganalisis data, dan menarik kesimpulan. ${ }^{7}$

Pendekatan pembelajaran saintifik adalah proses pembelajaran yang dirancang sedemikian rupa agar peserta didik secara aktif mengkontruk konsep, hukum dan prinsip melalui tahapan-tahapan, mengamati, merumuskan masalah, mengajukan hipotesis, mengumpulkan data, menganalisis data dan menarik kesimpulan, mengkomunikasikan konsep, hukum dan prinsip yang ditemukan. ${ }^{8}$

Adapun ciri kurikulum 2013 yang paling mendasar pada pendekatan saintifik adalah guru harus lebih banyak mencari tahu dari berbagai sumber belajar, karena saat ini peserta didik dapat dengan mudah mencari informasi dengan bebas melalui perkembangan teknologi dan informasi, sedangkan ciri peserta didik adalah peserta didik secara aktif mampu mengonstruk konsep dan prinsip melalui tahapan-tahapan mengamati, merumuskan masalah mengajukan atau merumuskan hipotesis mengumpulkan data dengan berbagai teknik, menganalisis data menarik kesimpulan dan mengkomunikasikan konsep.

\section{Implementasi Strategi Pembelajaran Melalui Pendekatan Saintifik}

Pembelajaran kurikulum yang sedang digagas pemerintah Indonesia yakni kurikulum 2013 melalu pendekatan ilmiah (saintifik), yakni proses pembelajaran yang dirancang sedemikian rupa agar peserta didik secara aktif mengonstruk konsep, hukum, atau prinsip melalui tahapan-tahapan mengamati, merumuskan masalah, mengajukan atau merumuskan hipotesis, mengumpulkan data dengan berbagai teknik, menganalisis data, menarik kesimpulan dan mengomunikasikan konsep, hukum, atau prinsip yang ditemukan.

Pembelajaran siswa aktif mencari semakin diperkuat dengan strategi pembelajaran sepeti pendekatan saintifik tersebut. Pada kondisi seperti ini, tentu saja proses pembelajaran harus tetap menerapkan nilainilai atau sifat-sifat ilmiah dan menghindari nilai-nilai atau sifat-sifat non ilmiah. Pendekatan saintifik dalam pembelajaran disajikan melalui strategi sebagai berikut:

a. Mengamati (Observasi). Metode mengamati mengutamakan kebermaknaan proses pembelajaran. Metode ini memiliki keunggulan tertentu, seperti menyajikan media obyek secara nyata, peserta didik senang dan tertantang, dan mudah pelaksanaannya.Metode mengamati sangat bermanfaat bagi pemenuhan rasa ingin tahu peserta didik. Sehingga proses pembelajaran memiliki kebermaknaan yang tinggi.

b. Menanya. Pertanyaan yang bersifat faktual sampai kepada pertanyaan yang bersifat hipotetik. Dari situasi dimana peserta didik dilatih menggunakan pertanyaan dari guru, masih memerlukan bantuan guru untuk mengajukan pertanyaan sampai ke tingkat dimana peserta didik mampu mengajukan pertanyaan secara mandiri. Dari kegiatan kedua dihasilkan sejumlah pertanyaan. Melalui kegiatan bertanya dikembangkan rasa ingin tahu peserta didik.Semakin terlatih dalam bertanya maka rasa ingi

${ }^{6}$ M. Musfiqon \& Nurdyansyah, Pendekatan Pembelajaran Sanitifik (Sidoarjo: Nizamia Learning Center, 2015), hlm. 37.

${ }^{7}$ Daryanto, Pendekatan Pembelajaran Sanitifik Kurikulum 2013 (Yogyakarta: Gava Media, 2014), hlm. 51.

${ }^{8}$ M. Hosnan, Pendekatan Saintifik dan Kontekstual dalam Pembelajaran Abad 21 (Bogos: Ghalia Indonesia, 2014), hlm. 34. 


\section{Jurnal Pendidikan Sains dan Komputer}

tahu semakin dapat dapat dikembangkan. Pertanyaan tersebut menjadi dasar untuk mencari informasi yang lebih lanjut dan beragam dari sumber yang ditentukan guru sampai yang ditentukan peserta didik, dari sumber yang tunggal sampai sumber yang beragam.

c. Mengumpulkan Informasi. Kegiatan mengumpulkan informasi merupakan tindak lanjut dari bertanya. Kegiatan ini dilakukan dengan menggali dan mengumpulkan informasi dari berbagai sumber melalui berbagai cara. Untuk itu peserta didik dapat membaca buku yang lebih banyak, memperhatikan fenomena atau objek yang lebih teliti, atau bahkan melakukan eksperimen. Dari kegiatan tersebut terkumpul sejumlah informasi.

d. Mengasosiasikan/Mengolah Informasi/Menalar. Kegiatan mengaso-siasi atau mengolah informasi atau menalar dalam kegiatan pembelajaran sebagaimana disampaikan disampaikan dalam Permendikbud Nomor 81 tahun 2013 adalah memproses informasi yang sudah dikumpulkan baik terbatas dari hasil kegiatan mengumpulkan atau eksperimen maupunhasil dari kegiatan mengamati dan kegaiatan mengumpulkan informasi. Pengolahan informasi yang dikumpulkan dari yang bersifat menambah keluasan dan kedalaman sampai kepada pengolahan informasi yang bersifat mencari solusi dari berbagai sumber yang memiliki pendapat yang berbeda sampai kepada yang bertentangan.

e. Mengkomunikasikan. Pada pendekatan scientific guru diharapkan memberi kesempatan kepada peserta didik untuk mengkomunikasikan apa yang telah mereka pelajari. Kegiatan ini dapat dilakukan melalui menuliskan atau menceritakan apa yang ditemukan dalam kegiatan mencari informasi, mengasosiasikan dan menemukan pola. Hasil tersebut disampaikan di kelas dan dinilai oleh guru sebagai hasil belajar peserta didik atau kelompok peserta didik tersebut. ${ }^{9}$

Kelima langkah dalam pendekatan saintifik tersebut dapat dilakukan secara berurutan atau tidak berurutan, terutama pada langkah pertama dan kedua. Sedangkan pada langkah ketiga dan seterusnya sebaiknya dilakukan secara berurutan. Langkah ilmiah ini diterapkan untuk memberikan ruang lebih pada peserta didik dalam membangun kemandirian belajar serta mengoptimalkan potensi kecerdasan yang dimiliki. Peserta didik diminta untuk mengkonstruk sendiri pengetahuan, pemahaman, serta skill dari proses belajar yang dilakukan, sedangkan tenaga pendidik mengarahkan serta memberikan penguatan dan pengayaan tentang apa yang dipelajari bersama peserta didik. ${ }^{10}$

Secara konsep pendekatan ini lebih mengarah pada model pendidikan humanis, yaitu pendidikan yang memberikan ruang pada peserta didik untuk berkembang sesuai potensi kecerdasan yang dimiliki. Peserta didik menjadi pusat belajar, tidak menjadi obyek pembelajaran. Dengan demikian karakter, skill, serta kognisi peserta didik dapat berkembang secara lebih optimal. ${ }^{11}$

\section{METODE}

Penelitian ini merupakan sebuah studi kualitatif yang akan mengungkapkan, menemukan dan menggali informasi tentang budaya kerja kepala madrasah dalam disiplin kerja guru di Madrasah Ibtidaiyah Negeri 4 Muaro Jambi. Metode penelitian kualitatif adalah metode penelitian dengan ciri filsafat postpositivisme, obyeknya yang alamiah, peneliti adalah sebagai instrumen kunci, pengambilan sampel dengan purposive samping, teknik pengumpulan dengan traingulasi (gabungan), analisis data bersifat

${ }^{9}$ Bekti Taufik Ari Nugroho, Implementasi Pendekatan Saintifik dalam Pembelajaran Pendidikan Agama Islam (Yogyakarta: Deepublish, 2016), hlm. 115-119.

${ }^{10}$ M. Musfiqon \& Nurdyansyah, op. cit., hlm. 40.

${ }^{11}$ Ibid., hlm. 40. 


\section{Jurnal Pendidikan Sains dan Komputer}

kualitatif, dan hasil penelitian lebih menekankan makna. ${ }^{12}$ Metode ini disebut juga sebagai metode artistik, karena proses penelitian lebih bersifat seni (kurang terpola), dan disebut sebagai metode interprestif karena data hasil penelitian lebih berkenaan dengan interprestasi terhadap data yang ditemukan di lapangan. ${ }^{13}$ Pemunculan karakter penelitian kualitatif di atas menjadi pedoman penelitian, yang nantinya mengarahkan terbentuknya pola penelitian yang global.

\section{HASIL}

MIN 4 Muaro Jambi beralamat di Jambi-Muara Bulian KM. 13 Desa Pematang Gajah Kecamatan Jambi Luar Kota Kabupaten Muaro Jambi sebagai salah satu Madrasah Ibtidaiyah Negeri yang ada di kabupaten ini. Madrasah sudah menyelenggarakan strategi pembelajaran dengan pendekatan sainfitik. Perencanaan pembelajaran saintifik berbasis kurikulum 2013 sudah dilakukan untuk mengkoordinasikan komponen silabus yaitu identifikasi, standar kompetensi, kompetensi dasar, materi pokok, pengalaman belajar, indikator, penilaian, alokasi waktu dan sumber/bahan/ alat. Senada dengan itu, kepala sekolah sebagai berikut: "Pelaksanaan pembelajaran saintifik kurikulum 2013 harus sesuai dengan visi MIN 4 Muaro Jambi yaitu menciptakan generasi yang cerdas, berakhlak mulia berdasarkan iman dan takwa." 14

Pelaksanaan kurikulum 2013 membutuhkan guru-guru yang memilili skill dan kualitas yang baik. Penyusun silabus SKI harus menguasai berbagai keahlian tentang sejarah Islam. Oleh karena itu, agar silabus tersusun dengan baik maka perlu bekerja sama secara baik dan terkoordinasi di antara guru. Pengamatan terhadap guru SKI di mana untuk menerapkan pendekatan saintifik dalam kurikulum 2013 maka guru mengembangkan silabus. Kemudian, silabus dijabarkan dalam Rencana Pelaksanaan Pembelajaran (RPP), kemudian dilaksanakan, dievaluasi dan ditindaklanjuti oleh masing-masing guru termasuk guru SKI. ${ }^{15}$

Dalam hal ini guru SKI menjelaskan sebagai berikut: Rencana Pelaksanaan Pembelajaran (RPP) yang saya siapkan dengan memperhatikan tagihan kurikulum 2013 pada pendekatan saintifik dengan mengidentifikasi dengan mengisi kolom identitas, menentukan alokasi waktu, menentukan standar kompetensi, kompetensi dasar serta indikator, merumuskan tujuan pembelajaran, mengidentifikasi materi pokok, menentukan metode pembelajaran, merumuskan langkah-langkah pembelajaran kegiatan awal, kegiatan inti, kegiatan akhir, menyusun kriteria penilaian, lembar pengamatan, contoh soal dan teknik penskoran. ${ }^{16}$

\section{PEMBAHASAN}

Berdasarkan hasil pengamatan yang penulis lakukan terhadap guru SKI yang membuat Rencana Pelaksanaan Pembelajaran (RPP) saintifik sesuai kurikulum 2013 dimana guru memulainya dengan mengisi kolom identitas, menentukan alokasi waktu, menentukan standar kompetensi, kompetensi dasar, serta indikator, merumuskan tujuan pembelajaran, mengidentifikasi materi pokok, menentukan metode pembelajaran, merumuskan langkah-langkah pembelajaran kegiatan awal, kegiatan inti, kegiatan akhir, menyusun kriteria penilaian, lembar pengamatan, contoh soal, dan teknik penskoran. Guru hanya membawa buku pelajaran SKI dari beberapa penerbit saadanya, buku tulis berisi ringkasan materi pelajaran

\footnotetext{
${ }^{12}$ Sugiyono, Metode Penelitian Pendidikan: Pendekatan Kuantitatif, Kualitatif dan R \&D, (Bandung: Alfabeta, 2007), hlm. 14.

${ }^{13}$ Ibid., hlm. 13-15.

${ }^{14}$ Wawancara, 4 November 2021

${ }^{15}$ Observasi, 4 November 2021

${ }^{16}$ Wawancara, 4 November 2021
} 


\section{Jurnal Pendidikan Sains dan Komputer}

kelas VIII. ${ }^{17}$

Berdasarkan pengamatan penulis di atas bahwa Silabus dan Rencana Pelaksanaan Pembelajaran (RPP) saintifik berbasis kurikulum 2013 disusun secara sistematis, utuh dan menyeluruh dengan beberapa kemungkinan penyesuaian dalam situasi pembelajaran yang aktual. Dengan demikian Silabus dan Rencana Pelaksanaan Pembelajaran (RPP) berfungsi untuk mengefektifkan proses pembelajaran sesuatu apa yang direncanakan. "Pelaksanaan pembelajaran saintifik kurikulum 2013 harus sesuai dengan visi MIN 4 Muaro Jambi yaitu menciptakan generasi yang cerdas, berakhlak mulia berdasarkan iman dan takwa."18

Pelaksanaan kurikulum 2013 membutuhkan guru-guru yang memilili skill dan kualitas yang baik. Penyusun silabus SKI harus menguasai berbagai keahlian tentang sejarah Islam. Oleh karena itu, agar silabus tersusun dengan baik maka perlu bekerja sama secara baik dan terkoordinasi di antara guru. Langkah-langkah pembelajaran saintifik terdiri atas lima pengalaman belajar pokok yaitu: mengamati, menanya, menalar, mengasosiasi dan mengkomunikasikan (mengkreasikan). Berdasarkan fakta fakta yang terjadi pada MIN 4 Muaro Jambi pada pembelajaran SKI dengan pendekatan Saintifik:

Tahap Mengamati. Berdasarkan wawancara dengan Guru SKI menjelaskan bahwa: Kenyataan dalam mengamati adalah siswa MIN 4 Muaro Jambi mengamati buku teks dan gambar tetapi siswa kurang fokus malah bercanda dengan teman sebangku dan guru belum mampu atau mengalami kesulitan membawa siswa pada konsentrasi penuh. ${ }^{19}$

Kesulitan dari guru karena gambar yang ditampilkan guru hanya mengunakan gambar pada kertas print, jarang mengunakan infokus karena terkadang infokus dipakai oleh guru lain kurangnya sarana dan prasana, tetapi guru selalu berusaha memberikan gambar yang menarik sesuai dengan tema, serta kurang minatnya siswa dalam mata pelajaran SKI atau kurang serius. ${ }^{20}$

Wawancara dengan guru SKI menjelaskan bahwa: "Kesulitan siswa MIN 4 Muaro Jambi adanya teman yang terkadang menganggu atau mengajak bercanda teman sebangkunya atau printnya yang terkadang kurang jelas." 21

Tahap Bertanya. Bertanyaan adalah kegiatan atau aktivitas dasar bagi siswa karena dengan aktivitas ini siswa bisa mendapatkan informasi yang diingkannya. Berdasarkan data di lapangan menemukan bahwa aktivitas dalam menanya adalah guru mata pelajaran SKI berusaha membangun semangat pada siswa untuk bertanya tentang kompetensi dasar yang ada tetapi minat tersebut kurang muncul pada diri siswa sehingga yang bertanya hanya sedikit atau berulangkali siswa yang sama bertanya. Hal ini mengakibatkan guru mata pelajaran SKI yang lebih aktif bertanya untuk menghidupkan suasana pembelajaran agar menjadi efektif, tetapi sisi negatifnya siswa menjadi terbiasa dengan guru mata pelajaran SKI yang memberikan perrtanyaan dibanding siswa yang aktif untuk bertanya. ${ }^{22}$

Tahap bernalar. Untuk dapat melakukan kegiatan berpikir ilmiah yang baik perlu ditunjang dengan alternatif sarana ilmiah berupa logika dan aktivitasnya disebut bernalar. Berdasarkan temuan wawancara dengan guru SKI dapat diketahui bahwa: Berdasarkan wawancara dengan Guru SKI menjelaskan bahwa:

\footnotetext{
${ }^{17}$ Observasi, 4 November 2021

${ }^{18}$ Wawancara, 11 November 2021

${ }^{19}$ Wawancara, 11 November 2021

${ }^{20}$ Observasi, 11 November 2021

${ }^{21}$ Wawancara, 11 November 2021

${ }^{22}$ Observasi, 11 November 2021
} 


\section{Jurnal Pendidikan Sains dan Komputer}

Fakta dalam menalar saya mengharapkan dalam tahapan menalar ini siswa mampu berfikir luas tentang tema yang disajikan, Kegiatan mengolah informasi atau menalar guru dan siswa juga melakukan tanya jawab tentang informasi yang sudah diperoleh siswa dan pada saat kegiatan mengumpulkan informasi. ${ }^{23}$

Berdasarkan observasi dengan Guru SKI menemukan bahwa guru memilih memakai metode ceramah sehingga yang menjadi sumber informasi adalah guru dan siswa hanya mendengarkan tanpa mencari sendiri informasi yang harusnya mereka dapatkan sehingga disini siswa harus mampu menyerap apapun informasi yang diberikan guru dengan cepat tanpa memahami dengan benar akan informasi-informasi tersebut. $^{24}$

Suatu proses berpikir dalam menarik suatu kesimpulan pengetahuan disebut penalaran. Berpikir adalah suatu aktivitas untuk menemukan pengetahuan yang benar atau kebenaran. Kebenaran itu bersifat individual, karena itu aktivitas proses berpikir manusia guna menghasilkan pengetahuan yang benar itu juga kriteria kebenaran sebagai landasan bagi proses penemuan kebenaran.

Tahap mengasosiasi. Dengan cara mengasosiakan mencari informasi melalui buku bacaan yang lain, internet, musyawarah komunikasi dengan siswa lainnya. Observasi penulis menemukan bahwa kesulitan dari tahapan menalar dan mengasosiasikan adalah kurangnya data yang dapat digali karena kurangnya buku yang ada diperpustakaan dan tidak boleh menggunakan internet karena MIN 4 Muaro Jambi ada pada lingkup pondok pesantren yang melarang mengunakan HP ditambah kurang maksimalnya pemakaian Komputer pada Sekolah. ${ }^{25}$

Kemudian guru mata pelajaran SKI juga belum dapat mengubah mindset berpikir di mana seharusnya kurikulum 2013 yang menggunakan pendekatan pembelajaran berbasis saintifik dimaksudkan untuk memberikan pemahaman kepada peserta didik dalam mengenal, memahami berbagai materi menggunakan pendekatan ilmiah, bahwa informasi dapat berasal dari mana saja, kapan saja, tidak bergantung pada informasi searah dari guru. Tetapi pada kenyataannya guru mata pelajaran SKI sendiri masih menggunakan pola pikir teacher centered dimana guru yang lebih banyak aktif daripada siswa dalam pembelajaran. Karena tidak memberikan kepercayaan kepada siswa. ${ }^{26}$

Tahapan mengkomunikasikan (mengkreasikan). Hasil belajar SKI juga belum berjalan dengan cukup baik karena beberapa kesulitan yang dialami seperti pada saat anak-anak presentasi untuk mengkomunikasikan hasil dari kegiatan diskusi dan penalaran yang dilakukan pada kegiatan sebelumnya. Observasi penulis dimana masalah alokasi waktu juga menjadi kendala tersendiri didalam implementasi aspek kemampuan mengkomunikasikan hasil belajar. ${ }^{27}$

Penetapan dan penentuan evaluasi harus didasarkan pada upaya pemenuhan tujuan pengajaran, serta tidak boleh menyimpang dari kurikulum 2013 yang telah ditentukan dan bahan harus tersusun rapi. Sebagaimana dikemukakan oleh guru SKI berikut ini: "Saya berusaha menyajikan evaluasi yang beragam dan bisa menilai siswa dari berbagai aspek dirinya di kelas, terutama pada UTS (Ujian Tengah Semester) dan UAS (ujian Akhir Semester) di MIN 4 Muaro Jambi."28

\footnotetext{
${ }^{23}$ Wawancara, 24 November 2021

${ }^{24}$ Observasi, 24 November 2021

${ }^{25}$ Observasi, 24 November 2021

${ }^{26}$ Observasi, 24 November 2021

${ }^{27}$ Observasi, 24 November 2021

${ }^{28}$ Wawancara, 24 November 2021
} 
Sementara itu wawancara dengan seorang siswa yang mengikuti proses pembelajaran SKI yang mengatakan berikut ini: "Guru SKI di MIN 4 Muaro Jambi setiap kali akan melakukan evaluasi selalu berusaha menilai hasil belajar kami setiap hari." 29 Berdasarkan keterangan di atas, berarti guru telah memiliki strategi yang tepat dalam meningkatkan evaluasi pembelajaran mata pelajaran SKI tersebut. Kesadaran akan kondisi demikian membuat guru telah mengevaluasi kinerjanya.

\section{KESIMPULAN}

Strategi pembelajaran melalui pendekatan saintifik pada mata pelajaran SKI di MIN 4 Muaro Jambi guru sudah menjabarkan kurikulum untuk menggunakan pendekatannya ini. Pada pelaksanaanya pendekatan ini tidak sepenuh sesuai perencanaan karena banyak aspek yang menjadi permasalahan seperti siswa bertanya yang sedikit, kemampuan bernalar yang rendah, kemampuan mengasosiasi yang keterbatasan media dan waktu.

Kepada kepala sekolah untuk memperhatikan dan meningkatkan penerapan pendekatan saintifik pada pembelajaran SKI. Kepala sekolah juga perlu responsif dalam mengirim guru mengikuti pelatihanpelatihan bertemakan kurikulum. Kepada guru untuk selalu meningkatkan pelaksanaan kurikulum 2013 dengan penerapan pendekatan saintifik.

\section{REFERENSI}

Ahmad Rohani, Pengelolaan Pengajaran, Jakarta: Rineka Cipta, 2004.

Bekti Taufik Ari Nugroho, Implementasi Pendekatan Saintifik dalam Pembelajaran Sejarah Kebudayaan Islam. Yogyakarta: Deepublish, 2016.

Daryanto, Pendekatan Pembelajaran Saintifik Kurikulum 2013. Yogyakarta: Gava Media, 2014.

Departemen Pendidikan Nasional, Strategi Pembelajaran dan Pemilihannya, Jakarta: Direktorat Tenaga Kependidikan, 2008.

E. Kosasih, Strategi Belajar dan Pembelajaran: Implementasi Kurikulum 2013. Bandung: Yrama Widia, 2014.

M. Hosnan, Pendekatan Saintifik dan Kontekstual dalam Pembelajaran Abad 21. Bogos: Ghalia Indonesia, 2014.

M. Musfiqon \& Nurdyansyah, Pendekatan Pembelajaran Sanitifik. Sidoarjo: Nizamia Learning Center, 2015.

Sugiyono, Metode Penelitian Pendidikan: Pendekatan Kuantitatif, Kualitatif dan $R \& D$, Bandung: Alfabeta, 2007.

Syaiful Bahri Djamarah dan Aswan Zain, Strategi Belajar Mengajar, Jakarta: Rinek Cipta, 2002, hlm. 5.

Wina Sanjaya, Strategi Pembelaran Berorientasi Standar Proses Pendidikan. Jakarta: Kencana, 2011.

${ }^{29}$ Wawancara, 24 November 2021 